\title{
Література:
}

1. Засіб із гепатопротекторною та спермомодулюючою дією у формі капсул: пат. 115714 Україна: МПК А61K 31/16, А61К 9/48 (2006.01). № u201611197; заявл. 07.11.16; опубл. 25.04.17, Бюл. № 8.6 c.

2. Селен - інструкція, застосування, аналоги препарату. URL: https://www.unian.ua/health/pharm/s/14486-selen-instrukciya-primenenieanalogi-preparata (дата звернення 10.12.2021).

3. Державна Фармакопея України 2-е вид. Доповнення 4. Харків. $2020.600 \mathrm{c}$.

DOI https://doi.org/10.30525/978-9934-26-182-4-33

\section{ВПЛИВ ОЛІЇ НАСІННЯ ВИНОГРАДУ ТА ОБЛІПИХОВОЇ ОЛІЇ НА ДИНАМІКУ ДЕЯКИХ БІОХІМІЧНИХ ПОКАЗНИКІВ КРОВІ У ЩУРІВ ТА ТЛІ ВИДАВЛЕНИХ ТРАФАРЕТНИХ РАН}

\author{
Сенюк I. B. \\ кандидат фармачевтичних наук, \\ дочент кафедри біологічної хімії \\ Національний фармачевтичний університет \\ Ленчик Л. В. \\ докторка фармачевтичних наук, професорка, \\ завідувачка кафедри якості, стандартизації та сертифікачії ліків \\ Інституту підвищення кваліфікаиії спеціалістів фармації \\ Начіональний фармацевтичний університет \\ м. Харків, Україна
}

Лікування ран залишається однією з найважливіших проблем сучасної медицини. Механічні та термічні ураження шкіри $є$ одними 3 найпоширеніших видів побутових та виробничих травм. Хворі, що мають гнійні рани різного походження, складають значну частину пацієнтів стаціонарів хірургічного профілю [1, с. 547-551].

На теперішній час більшість препаратів для місцевого лікування ран у 2-й та 3-й фазах ранового процесу не відповідають сучасним вимогам та не забезпечують в повній мірі потреб практичної медицини. Тобто, виникає необхідність пошуку нових лікарських засобів, які поєднували б високу ефективність, безпечність та доступність для широких верств 122 
населення. У зв'язку з цим перспективним напрямком у сучасній медицині і фармакології є розробка та вивчення лікарських засобів рослинного походження, що є безпечними та можуть виявляти багатоспрямовану дію на рановий процес $[2$, с. $52-53 ; 3$, с.24; ].

Олія насіння винограду є діючою речовиною рослинного походження, що має бути перспективною у складі препаратів для місцевого лікування ран у 2-й та 3-й фазах ранового процесу. Це обумовлено високим вмістом в iї складі різних груп біологічно активних речовин, наявність яких дозволяє припустити широкий спектр біологічної активності, зокрема, репаративних та антиоксидантних властивостей. Вищезазначене обумовлює актуальність вивчення фармакологічних властивостей олії насіння винограду з метою обгрунтування ії практичного використання в якості діючої речовини або лікарського препарату при місцевому лікуванні ран [4, с. 4136-4142].

Метою роботи стало визначення активності маркерних ферментів цитолізу - трансаміназ (аланінамінотрансфераз (АлАТ), аспартатамінотрансфераз (АсАТ) та вмісту сечовини у сироватці крові дослідних тварин та тлі видавлених трафаретних ран.

Для оцінки впливу олії насіння винограду та обліпихової олії на репаративні процеси проводили визначення активності ферментівмаркерів цитолізу - АлАТ і АсАТ у сироватці крові піддослідних тварин. Порушення цілісності клітинних мембран та руйнування клітинних структур призводить до вивільнення у кров ферментів, що мають внутрішньоклітинну локалізацію, внаслідок чого їх активність у сироватці крові значно зростає.

Для визначення активності трансаміназ використовували уніфікований динітрофенілгідразиновий метод, запропонований S. Reitman та S. Frenkel [5, с. 323-230.]. Внаслідок реакції переамінування, що відбувається за участю АлАТ і АсАТ, утворюється піровиноградна (щавлевооцтова) кислота, яка в присутності 2,4-динітрофенілгідразину у лужному середовищі утворює забарвлений гідразон, який має характерний пік поглинання при довжині хвилі 500-560нм. Зазначений метод запропонований для визначення активності АлАТ та АсAТ у наборах фірми «Lachema» (Чехія).

Для оцінки інтенсивності деструкції тканинних білків у сироватці крові піддослідних тварин визначали вміст сечовини.

Вміст сечовини визначали за кольоровою реакцією 3 діацетилмонооксимом [6, с. 208-211]. Сечовина у присутності тіосемикарбазиду та солей феруму у сильнокислому середовищі утворює 3 діацетилмонооксимом сполуку червоного кольору, що характеризується максимумом 
поглинання при довжині хвилі 500-560 нм. Розрахунок концентрації сечовини проводили за відповідною формулою.

Дослідження динаміки біохімічних показників показало, що застосування олії насіння винограду та обліпихової олії супроводжувалося достовірним порівняно з контрольною патологією (КП) зменшенням активності АлАТ та АсAT, а також зниженням вмісту сечовини у сироватці крові дослідних тварин на дев'яту добу експерименту, що свідчить про суттєве зменшення виразності цитодеструктивних процесів. На 13-ту добу досліду відбувалася повна нормалізація активності маркерних ферментів у сироватці крові піддослідних тварин та рівня сечовини (Табл.1).

Таблиця 1

Вплив олії насіння винограду та обліпихової олії на динаміку деяких біохімічних показників крові у щурів (модель видавлених трафаретних ран) $(\mathbf{n}=8)$

\begin{tabular}{|c|c|c|c|}
\hline \multirow[b]{2}{*}{ Умови досліду } & \multicolumn{3}{|c|}{ Показники } \\
\hline & $\begin{array}{c}\text { АлАТ, } \\
\text { ммоль/г•Л }\end{array}$ & $\begin{array}{c}\text { АсAТ, } \\
\text { ммоль/г॰Л }\end{array}$ & $\begin{array}{c}\text { Сечовина, } \\
\text { ммоль/л }\end{array}$ \\
\hline $\begin{array}{c}\text { Інтактний } \\
\text { контроль }\end{array}$ & $0,61 \pm 0,06$ & $0,68 \pm 0,06$ & $5,80 \pm 0,56$ \\
\hline \multicolumn{4}{|c|}{5 доба дослідження } \\
\hline КП & $1,04 \pm 0,10^{*}$ & $1,08 \pm 0,15^{*}$ & $9,67 \pm 1,02 *$ \\
\hline $\begin{array}{l}\text { Олія насіння } \\
\text { винограду }\end{array}$ & $0,92 \pm 0,07^{*}$ & $0,93 \pm 0,13^{*}$ & $8,21 \pm 0,35 * / * *$ \\
\hline Обліпихова олія & $0,93 \pm 0,11^{*}$ & $0,95 \pm 0,11 *$ & $8,10 \pm 0,51 * / * *$ \\
\hline \multicolumn{4}{|c|}{9 доба дослідження } \\
\hline КП & $0,88 \pm 0,09 *$ & $0,98 \pm 0,09^{*}$ & $9,28 \pm 0,86^{*}$ \\
\hline $\begin{array}{c}\text { Олія насіння } \\
\text { винограду }\end{array}$ & $0,73 \pm 0,10 * / * *$ & $0,80 \pm 0,05 * / * *$ & $7,48 \pm 0,54 * / * *$ \\
\hline Обліпихова олія & $0,75 \pm 0,09 * / * *$ & $0,82 \pm 0,05 * / * *$ & $7,43 \pm 0,65 * / * *$ \\
\hline \multicolumn{4}{|c|}{13 доба дослідження } \\
\hline КП & $0,83 \pm 0,11^{*}$ & $0,77 \pm 0,08$ & $7,82 \pm 0,56^{*}$ \\
\hline $\begin{array}{c}\text { Олія насіння } \\
\text { винограду }\end{array}$ & $0,67 \pm 0,08$ & $0,75 \pm 0,06$ & $6,33 \pm 0,69 * *$ \\
\hline Обліпихова олія & $0,65 \pm 0,09$ & $0,75 \pm 0,10$ & $6,62 \pm 0,57 * *$ \\
\hline
\end{tabular}

Примітки:

* - розбіжність достовірна відносно інтактного контролю $(\mathrm{p} \leq 0,05)$;

** - розбіжність достовірна відносно контрольної патології $(\mathrm{p} \leq 0,05)$. 
Таким чином, у ході проведених експериментальних досліджень встановлено, що олія насіння винограду зменшувала виразність цитодеструктивних процесів.

\section{Література:}

1. Белоусова Т.А. Современные принципы наружной терапии воспалительных дерматозов. РМЖ. 2008. № 8. С. 547-551.

2. Бутко Я.А., Ткачева О.В. Ожоги кожных покровов: классификация и методы лечения. Провизор. 2008. № 2. С. 52-53.

3. Волянський Ю.Л., Гриценко І.С., Широбоков В.П. Вивчення специфічної активності протимікробних засобів: метод. рек. Київ, 2004. $56 \mathrm{c}$.

4. Gorbatsova J, Lõugas T, Vokk R, Kaljurand M. Comparison of the contents of various antioxidants of sea buckthorn berries using CE. Electrophoresis. 2007. P. 4136-4142.

5. Камышников В.С. Справочник по клинико-биохимической лабораторной диагностики: в 2 т. Беларусь, 2002. Т. 1. С. 323-230.

6. Строев Е.А., Макарова В.Г. Практикум по биологической химии. Москва: Высш. шк., 1986. С. 208-211. 